\title{
PEMETAAN FAKTOR DOMINAN YANG MEMPENGARUHI BABY SMOKER DI SUKABUMI
}

\section{DOMINANT FAKTOR MAPPING WHICH INFLUENCE OF BABY SMOKER BEHAVIOR IN SUKABUMI}

\author{
E Septiyani1a ,L Kusherawati ${ }^{1}$, D Puspitawari ${ }^{1}$, B Ramdhan ${ }^{1}$ \\ 1Fakultas Keguruan dan Ilmu Pendidikan, Universitas Muhammadiyah Sukabumi, Indonesia. \\ a Korespondensi: Erisa Septiyani, E-mail: Erisaspt@gmail.com \\ (Diterima: 08-07-2019; Ditelaah: 09-07-2019; Disetujui: 29-08-2019)
}

\begin{abstract}
This study aims to find the dominant influencing factors baby smoker 's behavior in Sukabumi. In 2017, Indonesia was represented as a baby smoker country. This shameful for Indonesia, therefore this behavior must be avoided and decided. The method of this study is a case study using data collection techniques, which are interviews, observing, and documentation. The researcher has chosen five respondents who have been interviewed to compare their statements. From the result of this study is found some factors which influence baby smoker 's behavior from their environmental factors. It consists of the family and society environment, religion, and education. From the result of the analysis, the factors are categorized and mapped into a dominant influence, and it shows that the dominant factors are family and social environment. However, the most significant factors come from a family environment that originated from parenting and family guidance when the children step on the imitating phase. All in all, the dominant factor's mapping shows that baby smoker 's behavior in Sukabumi is influenced by poor parenting and family guidance so that the children will imitate the behavior seen around it.

Keywords: Beby smoker, family environment, imitate phase, oral phase, society environment.
\end{abstract}

\begin{abstract}
ABSTRAK
Penelitian ini bertujuan untuk mencari faktor dominan yang mempengaruhi perilaku baby smoker di Sukabumi. Pada tahun 2017 Indonesia dinobatkan sebagai negara "baby smoker". Hal ini merupakan salah satu hal yang memalukan bagi Indonesia, sehingga perilaku tersebut harus dicegah dan diputuskan. Metode penelitian yang digunakan dalam penelitian ini merupakan metode studi kasus dengan teknik pengambilan data berupa wawancara, observasi, dan studi dokumentasi. Peneliti menggunakan lima responden yang diwawancarai untuk membandingkan beberapa pernyataan dari responden tersebut. Hasil dalam penelitian yaitu ditemukan beberapa faktor yang mempengaruhi perilaku baby smoker , diantaranya faktor lingkungan yang terdiri dari lingkungan keluarga dan lingkungan masyarakat, agama dan pendidikan. Hasil analisis faktor-faktor kemudian dilakukan kategorisasi dan dipetakan faktor dominan yang mempengaruhi perilakunya. Dari hasil analisis, ditemukan faktor yang dominan mempengaruhi perilaku baby smoker adalah lingkungan keluarga dan masyarakat. Namun, faktor terbesar adalah keluarga yang berasal dari pola asuh dan bimbingan keluarga itu sendiri ketika anak memasuki meniru anak. Kesimpulannya, pemetaan faktor dominan yang mempengaruhi perilaku baby smoker di Sukabumi dipengaruhi oleh pola asuh dan pengawasan orang tua yang kurang baik, sehingga anak akan meniru perilaku yang dilihat disekitarnya.
\end{abstract}


Kata Kunci: Beby smoker, fase oral, fase meniru, lingkungan masyarakat, lingkungan keluarga.

Septiyani, E., Kusherawati, L., Puspitasari, D., \& Ramdhan, B. (2019) . Pemetaan Faktor Dominan Yang Mempengaruhi Perilaku Baby Smoker di Sukabumi, Jurnal Sosial Humaniora 10(2), 75-82.

\section{PENDAHULUAN}

Menurut Peraturan Pemerintah Republik Indonesia Nomor 19 Tahun 2003 tentang pengamanan rokok bagi kesehatan menyatakan bahwa rokok ialah hasil olahan tembakau terbungkus termasuk cerutu atau bentuk lainnya yang dihasilkan dari nicotiana tabacum, nicotiana nustica, dan spesies lainnya atau sintesisnya yang mengandung nikotin dan tar dengan atau tanpa tambahan. Masalah merokok saat ini tidak hanya menjadi masalah bagi dunia tetapi juga bagi Indonesia. Indonesia termasuk negara yang mengkonsumsi rokok terbanyak. Jumlah perokok Indonesia mencapai 62.800 .000 orang yang menempatkan Indonesia pada peringkat pertama di Asia Tenggara sebagai negara yang memiliki jumlah perokok terbanyak (Rahayuningsih, 2015). Jika dilihat dari jumlah penduduk Indonesia 237,56 juta maka proporsi tersebut setara dengan 82 juta penduduk yang menjadi perokok aktif. Berdasarkan jenis pekerjaan, petani/nelayan/buruh adalah proporsi perokok aktif setiap hari yang terbesar (44,5\%) dibandingkan kelompok pekerjaan lainnya (Nasution, 2017).

Perilaku merokok merupakan perilaku yang sangat merugikan, tidak hanya bagi orang-orang yang memiliki ketergantungan akan rokok, akan tetapi bagi orang-orang yang berada di sekitar perokok tersebut. Kerugian yang ditimbulkan salah satunya dari sisi kesehatan, dimana pengaruh nikotin, karbonmonoksida, dan tar dapat memacu sistem kerja dari susunan sistem saraf pusat yang akan mengakibatkan tekanan darah meningkat dan detak jantung bertambah cepat (Bensley, 2009). Merokok dapat menyebabkan baby smoker mengalami pneumonia (Karami, 2017).

Menurut (Hasanah,2017), Indonesia merupakan satu-satunya negara yang telah dinobatkan sebagai Negara baby smoker. Salah satu kota di Indonesia yang memiliki kasus tersebut diantaranya Sukabumi, Jawa Barat. Baby smoker adalah calon dan perokok jangka panjang dan menempatkan mereka pada kerusakan kualitas generasi dan kematian dini yang sebenarnya dapat dicegah (Hasanah, 2014) dilansir dari (liputan6.com, 2018) bahwa tim medis dari Dinas Kesehatan Kabupaten Sukabumi, Jawa Barat, memberikan perhatian khusus terhadap baby smoker yang inisial RAP, balita berusia 2,5 tahun yang kecanduan merokok. Pasalnya semenjak RAP mulai merokok, sikapnya berubah menjadi pemarah. Selain itu dilansir dari (suara.com, 2018), Kantor Perlindungan Anak Indonesia Kabupaten Sukabumi menuturkan bahwa anak yang merokok dibawah usia lima tahun akan direhabilitasi sampai dengan sembuh, dan akan terus mengawasi proses dari rehabilitasi tersebut.

Secara psikologi anak, pada usia 2,5 tahun anak masuk ke dalam tahap atau fase meniru, dimana anak di bawah usia lima tahun akan menyerap semua pengalaman dan memindahkan ke dalam pengalaman pribadinya tanpa evaluasi dan seleksi ketat, sehingga anak akan meniru semua kegiatan yang ada disekitarnya (Wardianti dan Mayasari, 2016). Secara perkembangan, anak yang berusia 2,5 tahun masih berada dalam fase oral. Fase yang dimana masih menginginkan untuk menyusui pada ibunya, sehingga dapat disimpulkan bahwa hipotesis yang muncul dari permasalahan yang terjadi yaitu kemungkinan balita tersebut mengkonsumsi rokok untuk 
memuaskan masa oralnya tersebut dan meniru perilaku dari orang tua atau lingkungan sekitarnya yang merokok. Berdasarkan dari pernyataan dan hipotesis di atas, maka kasus tersebut pasti memiliki faktor-faktor yang mempengaruhi perilaku "baby smoker" , dan dari faktor-faktor tersebut, pasti adanya faktor yang paling dominan mempengaruhi perilaku baby smoker, sehingga perlu adanya pemetaan faktor-faktor dominan yang mempengaruhi perilaku "baby smoker" di Sukabumi.

Oleh karena itu, untuk menjawab hipotesis di atas, maka peneliti bermaksud untuk melakukan penelitian mengenai faktorfaktor yang mempengaruhi baby smoker , dan kemudian akan melakukan pemetaan faktor dominan penyebab dari baby smoker . Penelitian ini dilakukan dengan metode studi kasus serta pendekatan kualitatif dalam pemetaan faktor tersebut.

\section{MATERI DAN METODE}

Metode dalam Penelitian menggunakan metode kualitatif dengan pendekatan studi kasus. Penelitian studi kasus merupakan pengujian secara rinci terhadap satu latar atau satu orang subyek atau satu tempat penyimpanan dokumen atau satu peristiwa tertentu (Sugiyono, 2013). Secara garis besar, metode studi kasus dalam penelitian ini akan dilakukan melalui serangkaian kegiatan ilmiah secara intensif, terperinci, dan mendalam terhadap anak yang menjadi korban baby smoker. Dalam kegiatan ini akan dilakukan penelitian aktifitasnya baik pada tingkat perorangan, kelompok, lembaga, atau organisasi dilingkungan korban, untuk mendapatkan data yang diperlukan secara lengkap. Penelitian ini dilaksanakan di Desa Tenjojaya, Kec. Cibadak, Kab. Sukabumi pada bulan Mei 2019. Teknik pengumpulan data dilakukan dengan tiga cara yaitu wawancara, observasi, dan studi dokumentasi. Data-data tersebut kemudian dipilah-pilah, lalu peneliti melakukan reduksi data, yaitu suatu proses pemilahan, pemusatan perhatian, penyederhanaan, pengabstrakan, dan mentransportasikan data-data kasar yang muncul dari catatan yang tertulis dilapangan secara terus-menerus.

Setelah meneliti dan menelaah, maka peneliti melakukan sistem pengkodean untuk mempermudah penyusunan ke dalam satuan-satuan. Selanjutnya peneliti melakukan pemeriksaan terhadap keabsahan data yang diakhiri dengan penafsiran data sebagai pengolahan data sementara, kemudian menjadi teori substansif dengan menggunakan beberapa teori yang ada. Setelah itu, peneliti melakukan beberapa kategorisasi, yaitu salah satu tumpukan dari seperangkat tumpukan yang disusun atas dasar pikiraan, intuisi, pendapat, atau kriteria tertentu yang mengadaptasi teknik analisis data studi kasus menurut (Sugiyono, 2013). Berikut tabel metode pengambilan data serta responden dalam penelitian ini.

Tabel 1. Responden dan Teknik pengambilan data

\begin{tabular}{|c|c|c|c|}
\hline \multirow{2}{*}{ Responden } & \multicolumn{3}{|c|}{ Telmik Pengumpulan Data } \\
\hline & Wawancara & Observasi & Sudid Dolumentasi \\
\hline Orang tua & $\sqrt{ }$ & $\sqrt{ }$ & $\sqrt{ }$ \\
\hline Tetangas & $\checkmark$ & $\sqrt{ }$ & \\
\hline RTA & $\sqrt{ }$ & & \\
\hline RTI & $\checkmark$ & & \\
\hline PITPA & $\sqrt{ }$ & & \\
\hline Limglomgan Sekitar & & $\sqrt{ }$ & $\sqrt{ }$ \\
\hline
\end{tabular}

\section{HASIL DAN PEMBAHASAN}

RAP merupakan anak yang kini berusia \pm 2,5 tahun. RAP tinggal di Desa Tenjojaya, Kecamatan Cibadak, Kabupaten Sukabumi, Jawa Barat. Sehari-hari RAP tinggal bersama kedua orang tuanya dan 2 orang kakak perempuannya. Ayah RAP sehari-hari bekerja sebagai buruh serabutan, sedangkan ibunya membuka sebuah warung kecil. Dalam penelitian ini, peneliti melakukan wawancara terhadap beberapa responden, diantaranya keluarga, tetangga, RT setempat, dan lembaga P2TP2A. Setelah 
melakukan penelitian, peneliti menemukan beberapa fakta kasus yang digambarkan dalam mantrik berikut ini.

Berdasarkan matrik wawancara yang telah peniliti lakukan di atas, maka data dapa direduksi lagi menjadi beberapa bagian faktor diantaranya yaitu faktor keluarga, lingkungan, pendidikan dan agama. Disini peneliti berfokus pada faktorfaktor yang paling dominan yang menyebabkan baby smoker di Sukabumi

Tabel 2. Matrik wawancara responden terjadi. Dapat di lihat berdasarkan data di atas, bahwa faktor yang paling sering muncul adalah dari lingkungan dan bimbingan orang tua, dimana beberapa responden memberikan pernyataan bahwa di lingkungan sekitar terdapat orang-orang yang merokok, dan ditemukan puntung rokok. Hal tersebut sesuai dengan pernyataan orang tua RAP yang memberikan penjelasan mengenai perilaku awal RAP sehingga menjadi perokok.

\begin{tabular}{|c|c|c|c|c|}
\hline Orang Tua & Tetangga & RT 04 & RT 01 & P2TP2A \\
\hline $\begin{array}{l}\text {-Terdapat puntung } \\
\text { rokok yang ditemukan } \\
\text { disekitar rumah dan } \\
\text { suka melihat orang } \\
\text { merokok di warung } \\
\text { - Pendidikan terkahir } \\
\text { orang tua SD, dan } \\
\text { bekerja sebagai buruh } \\
\text { serabutan. } \\
\text { - Tidak dilakukan } \\
\text { tindakan rehabilitasi } \\
\text { dari pihak manapun. }\end{array}$ & $\begin{array}{l}\text { - Terdapat puntung } \\
\text { rokok yang } \\
\text { ditemukan disekitar } \\
\text { rumah, apabila RAP } \\
\text { mengamuk, orang } \\
\text { tua akan memberikan } \\
\text { rokok untuk RAP. } \\
\text { Orang tua RAP juga } \\
\text { merokok. } \\
\text {-Terkadang terdapat } \\
\text { beberapa tetangga } \\
\text { yang menawarkan } \\
\text { rokok } \\
\text {-Pendidikan terakhir } \\
\text { orang tua SD, dan } \\
\text { bekerja sebagai } \\
\text { buruh serabutan. }\end{array}$ & $\begin{array}{l}\text { - Orang tua RAP } \\
\text { merokok, jika RAP } \\
\text { mengamuk, orang } \\
\text { tua memberikan } \\
\text { rokok, terkadang } \\
\text { RAP suka } \\
\text { mengambil rokok } \\
\text { sendiri } \\
\text { warungnya. } \\
\text {-Pendidikan terakhir } \\
\text { orang tua SD, dan } \\
\text { bekerja sebagai } \\
\text { buruh serabutan. } \\
\text {-Orang tua jarang } \\
\text { ikut pengajian }\end{array}$ & $\begin{array}{l}\text { - Orang tua } \\
\text { memberikan } \\
\text { rokokkepada RAP } \\
\text { ketika RAP marah- } \\
\text { marah meminta } \\
\text { rokok } \\
\text {-Tidak pemah ikut } \\
\text { pengajian. }\end{array}$ & $\begin{array}{l}\text { - Dilingkungan } \\
\text { bayak yang } \\
\text { merokok } \\
\text {-Bimbingan orang } \\
\text { tua kurang } \\
\text {-Tidak ada tindakan } \\
\text { rehabilitasi yang } \\
\text { dilakukan. }\end{array}$ \\
\hline
\end{tabular}

"Awalnya RAP hanya mengumpulkan puntung rokok, dari puntung rokok itu kemudian dihisap dan di makan tembakaunya. Kemudian, suatu hari saya ke pasar bersama RAP, lalu tiba-tiba RAP marah-marah dan meminta rokok, lalu ayahnya membeli rokok dan diberikan ke RAP, lalu ada wartawan yang tidak sengaja memotret kegiatan RAP dan menyebarkan ke media sosial"
Hal tersebut juga sesuai dengan pernyataan dari tetangga korban yang menyatakan bahwa: "Tadinya RAP memungut puntung-puntung rokok di jalan, dan dihisap. Waktu ke pasar cibadak, tibatiba RAP meminta rokok, lalu di kasih sama bapaknya, sesudah itu di foto oleh wartawan, tidak sengaja. Kalau disini yaa kadang-kadang suka minta, kalau bapaknya 
ke pasar, biar gak nangis, dikasih sama bapaknya."

Selain itu, peneliti juga menanyakan apakah dari pihak keluarga terdapat beberapa orang yang merokok. Lalu hal tersebut dibenarkan oleh tetangga RAP yang menyatakan bahwa ayahnya terkadang merokok, tetapi tidak sering. Selain itu, berdasarkan hasil observasi, kami menemukan memang terdapat puntungpuntung rokok yang bergeletak di jalan. Selain itu, kami juga melihat salah satu keluarga yang tidak lain adalah pamannya RAP juga merokok. Dari hasil pernyataan respon di atas, maka faktor dapat di petakan sebagai berikut.
Gambar 1. Pemetaan factor dominan penyebab Baby smoker

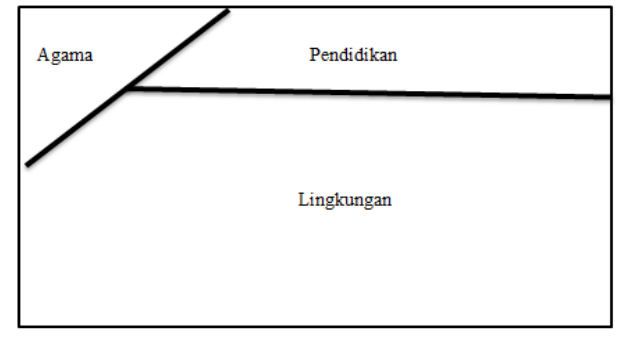

Berdasarkan gambar di atas, dapat dilihat bahwa faktor yang paling dominan penyebab baby smoker adalah faktor lingkungan. Berdasarkan hasil analisis, peneliti mengemukakan aspek dari faktor lingkungan yang mempengaruhi perilaku baby smoker sebagai berikut:

Gambar 2. Pemetaan factor dominan " baby smoker"

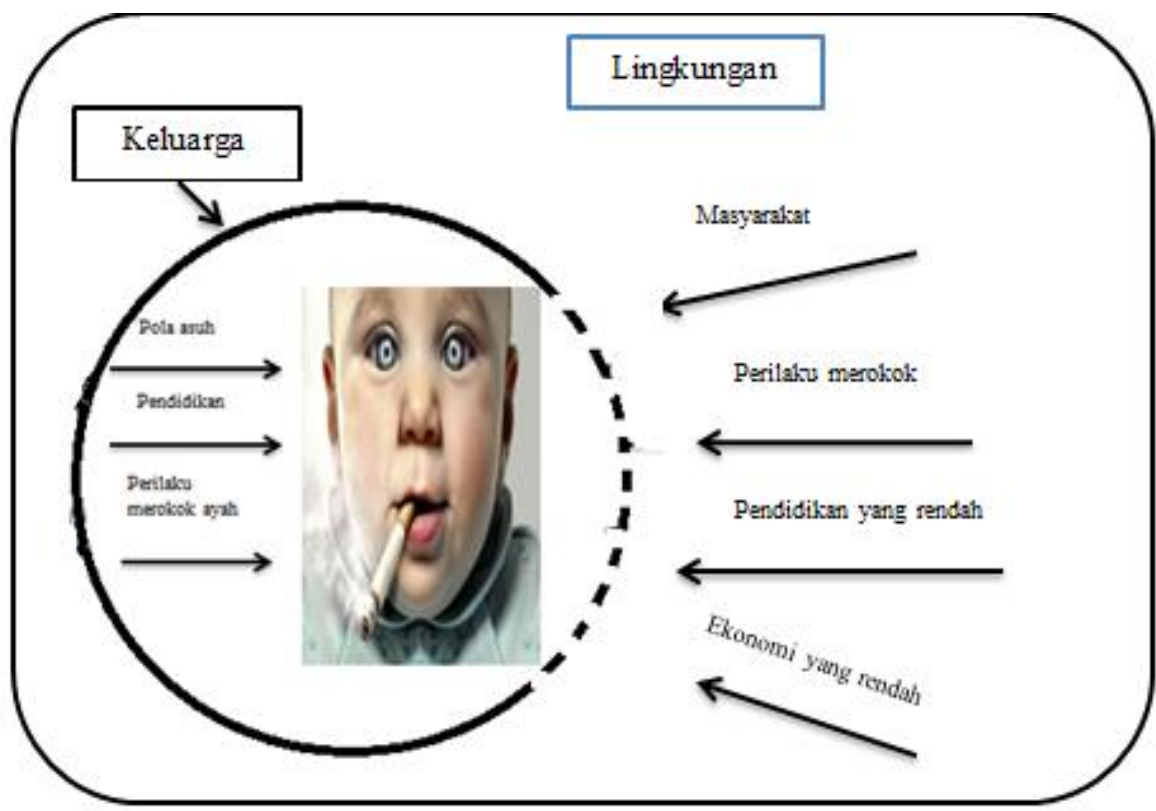

Gambar di atas menunjukan aspek faktor lingkungan yang menjadi faktor paling dominan penyebab perilaku baby smoker terjadi. Gambar tersebut dibuat berdasarkan beberapa pernyataan responden. Disini peneliti menggambarkan faktor lingkungan keluarga lebih besar dibandingkan dengan faktor lingkungan dari masyarakat sekita (tetangga, teman sebaya, dll). Berdasarkan dari pernyataan-pernyataan yang telah diungkapkan responden sebelumnya, faktor lingkungan menunjukan bagaimana lingkungan masyarakat sangat mendukung perilaku baby smoker dengan ditemukannya puntung rokok disekitar rumah, RAP melihat orang merokok, dan terdapat anggota keluarga (Paman RAP) merokok merupakan salah satu faktor terjadinya perilaku RAP merokok. Namun, hal tersebut menjadi lebih mengkhawatirkan ketika diketahui bahwa ayah dari RAP merokok, dan suka memberikan RAP rokok ketika marah-marah. Disini, hubungaan lingkungan keluarga sangat besar.

Menurut (Ramayulis, 1987) keluarga merupakan unit pertama dalam masyarakat 
dimana hubungan-hubungan yang terdapat di dalamnya sebagian besar sifatnya secara langsung. Disitulah perkembangan individu dan disitulah terbentuknya tahap awal perkembangan dan mulai interaksi dengannya, ia memperoleh pengetahuan, keterampilan, minat dan sikap dalam hidup. Dalam kasus ini, peran orang tua sangat besar terhadap perkembangan perilaku anak dalam masa perkembangannya. Kasus ini menunjukan bahwa pola asuh orang tua sangatlah penting. Menurut beberapa pernyataan responden, ketika RAP menangis, dan mengamuk orang tua selalu memberikan rokok kepada RAP. Hal tersebut merupakan cara pola asuh anak yang salah. Dampaknya, ketika RAP menginginkan rokok, RAP akan mengamuk kembali sampai diberikan rokok oleh orang tuanya. Selain itu, fakta pola asuh dari keluarga yang salah pun diperkuat dengan perilaku merokok pada ayahnya. Menurut konsep psikologis perkembangan, ada yang disebut dengan tahapan meniru anak (modeling). Menurut (Bandura, 1997) dan (Richard, 2010) perilaku meniru seseorang adalah hasil interaksi faktor dalam diri (kognitif). Ada proses pentingnya perilaku meniru diantaranya, perhatian (Attention process) adalah sebelum meniru orang lain, perhatian harus dicurahkan ke orang tersebut dan representasi (Representation process) adalah tingkah laku yang akan ditiru harus disimbolisasikan dalam ingatan. Salah satu dalam tingkah laku adalah meniru. Orang tua secara tidak langsung menjadi model yang ditiru oleh anak. Apa yang anak lihat dan pelajari dari orang tua akan dapat ditiru oleh anak-anaknya.

Dalam kasus ini, beberapa responden menyebutkan bahwa ayah dari RAP memang merokok, akan tetapi tidak terlalu sering. Penelitian ini sesuai dengan hasil penelitian yang dilakukan oleh (Melda , 2017) dimana lingkungan keluarga memiliki peranan besar dalam membentuk kepribadian anak dan merupakan lingkungan pertama yang dikenal anak, sehingga anak akan meniru perilaku yang dilakukan oleh orang tuanya. RAP kemungkinan mengenal rokok dari ayahnya terlebih dahulu, kemudian mulai mengumpulkan puntung-puntung rokok dan menghisapnya. Dalam kasus ini, tingkah laku orang tua di depan anak sangatlah penting untuk dijaga, sebab akibat yang akan ditimbulkan bisa jadi lebih buruk dari dugaan kita. Menurut Baer dan Corado (Dalam Mut'adin, 2002) mengemukakan bahwa anak-anak yang merokok berasal dari keluarga yang tidak bahagia, dimana orang tua tidak begitu memperhatikan anakanaknya. Selain adanya fase meniru, menurut perkembangan psikologis, anak yang berusia 2,5 tahun masuk ke dalam adanya fase oral dimana anak di bawah usia lima tahun akan menyerap semua pengalaman dan memindahkan ke dalam pengalaman pribadinya tanpa evaluasi dan seleksi ketat, sehingga anak akan meniru semua kegiatan yang ada disekitarnya (Wardianti dan Mayasari, 2016). Dugaan ini di dukung dengan pernyataan orang tuanya bahwa RAP berhenti menyusui sejak umur 3 bulan, sehingga kemungkinan fase oral yang seharusnya terjadi dalam usia 1 tahun terjadi lagi di usia 2,5 tahun untuk memuaskan keinginannya menyusui dan menghisap. Hasil penelitian ini tidak sesuai dengan hasil penelitian yang dilakukan oleh (Faridah, 2015) terhadap kasus remaja merokok yang menyatakan bahwa 60\% remaja merokok berasal dari teman sebayanya yang mengenalkan rokok kepada korban. Perbedaan hasil tersebut disebabkan karena subjek yang berbeda dimana penelitian yang dilakukan sebelumnya tersebut terjadi pada anak remaja, sedangkan pada penelitian ini terjadi pada balita berusia 2,5 tahun yang secara dominan masih belum mengenyam pendidikan dan masih dalam pengawasan penuh orang tuanya.

Penelitian ini sesuai dengan hasil penelitian yang dilakukan oleh (Wulan, 2012) sebelumnya. Hasil penelitian (Wulan, 2012) menyatakan bahwa faktor dominan yang mempengaruhi perilaku merokok pada remaja karena melihat orang tuanya merokok, dan saudara kandungnya merokok. Dalam penelitiannya, perilaku 
yang sering ditiru oleh anak remaja yang merokok sebagian besar adalah tingkah laku dari ayahnya sendiri.

Pola asuh merupakan kegiatan yang mencakup perilaku tertentu yang bekerja secara bersama-sama dimana akhirnya dapat memberikan pengaruh terhadap anak (Daling, dan Nency, 1999). Ada tiga tipe pola asuh orang tua terhadap anak menurut Diana Baumrind (Dalam Santrock, 2003) diantaranya yaitu; 1) Authoritarian parenting, yaitu orang tua terlalu mengekang anak-anaknya untuk mengikurti semua aturan yang dibuat oleh orang tua. Orang tua cenderung akan menghukum anaknya apabila tidak mengikuti aturan, 2) Authoritative parenting, yaitu sikap dimana orang tua cenderung tegas, dan selalu memberikan kepada anak, mendorong untuk saling membantu dan bertindak secara objektif, 3) Permissive parenting, yaitu sikap orang tua yang memberikan kebebasan terhadap anaknya untuk mengatur dirinya sendiri. Dalam kasus ini, pola asuh orang tua korban masuk ke dalam pola asuh permisif. Hal ini dibuktikan dengan pernyataan dari beberapa responden yang menyatakan "Anaknya ngamuk minta rokok, kemudian sama ayahnya dikasih biar anaknya gak nangis terus". Menurut (Santrock, 2003) menyatakan bahwa sikap orang tua yang permisif akan lebih mudah untuk memutuskan perilaku merokok tanpa berpikir konsekuensi yang diterimanya. Penelitian ini berbeda dengan penelitian yang dilakukan oleh (Safitri, dkk 2013) yang menyatakan bahwa semakin tinggi pola asuh authoritative parenting maka semakin tinggi pula perilaku merokok pada anak remaja.

Selain faktor lingkungan keluarga, faktor lingkungan masyarakat juga menjadi faktor dominan dalam adanya kasus ini. Lingkungan yang tidak representatif akan mempengaruhi bagaimana tingkah laku anak. Lingkungan dalam kasus ini bukanlah lingkungan teman sebaya, tapi merupakan orang yang termasuk ke dalam keluarga korban baik itu tetangga, ataupun saudaranya. Berdasarkan penelitian beberapa kasus merokok pada remaja, biasanya perilaku merokok paling besar disebabkan oleh adanya dorongan dari teman sebaya. Seperti hasil penelitian (Fathiah, 2015) dan (Melda, 2017) yang menyatakan bahwa faktor yang mendasari perilaku merokok pada remaja disebabkan oleh teman 60\%, diri sendiri 29,4\%, keluarga $9,4 \%$ dan hal lainnya sebanyak $1,2 \%$, yang dimana remaja cenderung mengikuti ajakan teman-temannya untuk merokok, sedangkan, dalam kasus ini aspek teman sebaya, berdasarkan hasil observasi peneliti, teman sebaya dari RAP tumbuh dan berkembang layaknya anak balita seperti biasa, dan tidak terpengaruh untuk merokok. Hasil wawancara dengan responden menyebutkan bahwa RAP mulai kecanduan merokok awalnya dimulai dengan mengumpulkan puntung-puntung rokok. Hal tersebut dapat terlihat jelas, bagaimana lingkungan sekitar korban itu merokok dan membuang puntungpuntungnya secara sengaja dijalanan, dan ditemukan oleh anak-anak. Lingkungan dalam pengertian psikologi berarti segala apa yang berpengaruh terhadap diri individu dalam berperilaku.

Selain itu, hal yang sangat mengkhawatirkan yang kami temukan adalah, setelah RAP diberitakan kecanduan merokok, masyarakat sekitar justru mengiming-imingi rokok untuk diberikan kepada RAP. Hal tersebut bukanlah tindakan yang benar. Lingkungan seperti itu mendukung adanya perilaku baby smoker terjadi, sehingga dalam hal ini pola asuh keluarga khususnya dari orang tua sangatlah penting untuk diperbaiki. Ketika lingkungan sangat mendukung perilaku menyimpang pada anak, orang tua harus membentengi anak dengan berbagai hal baik dalam pendidikan seperti disekolahkan, agar anak mengetahui sejak dini bagaimana bahaya merokok, dan agama yang jelas tidak memperbolehkan merokok, juga keluarga yang seharusnya tidak ada yang merokok sama sekali, agar anak dapat meniru perilaku yang baik dari orang tuanya. Dengan itu, seburuk apapun lingkungan sekitarnya, ketika pengawasan dan pola 
asuh keluarga kuat dalam mendidik dengan perilaku yang baik, maka lingkungan tidak akan masuk dan mempengaruhi perilaku buruk terhadap anak.

\section{KESIMPULAN}

Berdasarkan data dan analisis yang sudah dibuat, dapat disimpulkan bahwa dalam kasus ini faktor dominan yang sangat memperngaruhi perilaku baby smoker adalah faktor lingkungan. Faktor lingkungan keluarga mempengaruhi dalam pola asuh yang masuk ke dalam fase meniru anak dan pengawasan yang kurang baik, sedangkan dalam segi lingkungan masyarakat, adanya lingkungan yang tidak representatif menyebabkan perilaku baby smoker ini dapat terjadi. Solusi yang dapat dilakukan untuk mencegah terjadinya balita merokok kembali adalah dengan mengubah pola asuh keluarga dan pengawasan yang lebih baik terhadap anaknya. Serta orang tua yang harus memberikan contoh yang baik, agar dalam fase meniru anak, anak tidak akan meniru perilaku buruk dari orang tuanya.

\section{DAFTAR PUSTAKA}

Atkison, R. (2010). Pengantar Psikologi Jilid Satu. Tangerang: Interaksa.

Bandura, A. (1997). Social Learning Theory. New Jersey: Prentice-Hall.

Bensley, R. J. (2009). Metode Pendidikan Kesehatan Masyarakat. Jakarta: EGC.

Darling, dan Nancy. (1999). Parenting Stule and Its Correlates. US Departemen of Education: ERIC Digest.

Faridah, F. (2015). Analisis Faktor-Faktor Penyebab Perilaku Merokok Remaja di SMK "X" Surakarta. Jurnal Kesehatan Masyarakat, 3 (3),887-897.

Hasanah, H. (2017). Baby smoker : Perilaku Konsumsi Rokok Pada Anak dan Strategi Dakwahnya. Jurnal SAWWA,9 (2).

Karami, M, F. 2017. Kampanye Sosial Tentang Bahaya Asap Rokok Terhadap Balita (Bagi Ayah Perokok Aktif). Jurnal e-Proceeding of Art \& Design, 4 (3).
Melda, S. (2017). Faktor-Faktor Penyebab Remaja Merokok (Studi Kasus Remaja LakiLaki di Kelurahan Karang Asam Ulu Kecamatan Sungai Kunjang Kota Samarinda). E-Journal Sosiatri-Sosiologi, 5 (4), 102-116.

Mohammad, M. (2018). "Ketika Puntung Rokok Bikin Balita di Sukabumi Jadi Pemarah". [Online]. Tersedia pada liputan6.com. Dipunggah pada [30 Agustus 2018].

Nasution, H. (2017). Faktor-Faktor Yang Berhubungan Dengan Tindakan Merokok Kepala Keluarga Di Kelurahan Ujung Padang Kota Padang Sidimpuan Tahun 2017. Jurnal llmiah Kohesi, 1 (3).

Safitri, et al. (2013). Faktor-Faktor Yang Mempengaruhi Perilaku Merokok Pada Remaja. Tazkiyah Journal of Psychology, 18 (1), 47-65.

Santrock, J.W. (2003). Adolescenes., eleventh edition. Remaja, edisi sebelas. Benedictine Widyasinta (terj). Jakarta: PT Gelora Aksara Pratama.

Rahayuningsih, F. (2015). "Hubungan antara Persepsi Perilaku Merokok dengan Perilaku Merokok Siswa SMK X di Kota Semarang". (Skripsi). Semarang: Fakultas Kesehatan Masyarakat Universitas Diponegoro.

Ramayulis. (1987). Pendidikan Islam Dalam Rumah tangga. Jakarta: Kalam Mulia

Riskesdas. (2010). Riset Kesehatan Dasar. Riskesdas 2010. Jakarta: Kementerian Kesehatan Indonesia.

Santoso, B. (2018). Diduga Kecanduan, Balita Sukabumi Isap 2 Bungkus Rokok Sehari. [Online]. Tersedia pada suara.com. Dipunggah pada [30-Agustus-2018].

Sugiyono. (2013). Memahami Penelitian Kualitatif. Yogyakarta: PT. Lukis Pelangi Aksara

Wardianti Y, dan D, Mayasari. (2016). Pengaruh Fase Oral Terhadap Perkembangan Anak. Jurnal Bimbingan dan Konseling Indonesia, 1 (2),36-37.

Wulan, D. K. (2012). Faktor Psikologis Yang Mempengaruhi Perilaku Merokok Pada Remaja. Jurnal Humaniora, 3 (2), 504-514. 